doi:10.18575/msrs.sm.e.16.19

UDK 616.711-007.5:616.14 COBISS.RS-ID 6163992

\section{Varicose Veins and Uterine Prolapse in Female Patients Treated for Idiopathic Scoliosis}

\section{ABSTRACT}

Introduction: In the available literature there are sporadic data about the relationship between the impaired collagen synthesis and poor posture on one side, and the occurrence of varicose veins and uterine prolapse on the other side. However, there are no studies which specifically target this issue.

Aim of the Study: To determine the prevalence of varicose veins and/or uterine prolapse occurrence in women previously treated for idiopathic scoliosis in comparison to the control group - women who have never been treated for idiopathic scoliosis.

Patients and Methods: The study was designed as a cross-sectional study. The frequency of occurrence of varicose veins and/or uterine prolapse in a group of women previously treated for scoliosis was compared with a control group. The results were obtained through descriptive analysis and through conclusive results of statistical tests, where $p<0.05$ was set as a statistically significant value.

Results: In comparison to the control group, the frequency of varicose veins occurrence was higher, with a statistically significant difference in the group of women treated for idiopathic scoliosis. There was not a single case of uterine prolapse.

Conclusion: Modern approach to scoliosis treatment requires the involvement of multidisciplinary teams for scoliosis in specialized health care facilities which have developed the expertise in this field. These teams should work on prevention, early detection and diagnosis, promoting the adequate treatment approaches anchored in evidence based medicine, but also get involved in the continuous research striving to improve the quality of life of their patients.

Key words: idiopathic scoliosis, varicose veins, uterine prolapse, collagen

(Scr Med 2016:47:114-120)
Goran Talić, ${ }^{1}$ Ljerka Ostojić, ${ }^{2}$ Tatjana Nožica-Radulović, ${ }^{1}$ Durdica Stevanović-Papić ${ }^{1}$

${ }^{1}$ Institute of Physical Medicine and Rehabilitation „Dr Miroslav Zotovic“ Banja Luka

${ }^{2}$ Faculty of medicine, University of Mostar

\section{Contact address:}

Goran Talić

Institute of Physical Medicine and Rehabilitation „Dr Miroslav Zotovic“ Banja Luka

78 ooo Banja Luka

Republic of Srpska

Bosnia and Herzegovina

Telephone: +38765516042

E-mail:

kancelarija.direktora@zotovicbl.com

Submitted: June $28^{\text {th }}, 2016$ Accepted: July 16 $6^{\text {th }}, 2016$

\section{Introduction}

Spine deformities represent $27.5 \%$ of all deformities of locomotor apparatus. Spine deformities include functional or structural changes of spine, esthetic problems, back pain and functional impairments of cardiovascular and respiratory systems. According to the Scoliosis Research
Society, scoliosis is every lateral deviation of the spine in frontal plane with an angle greater than ten degrees per Cobb. (Figure1.). ${ }^{1}$ 
Figure 1. Measuring the scoliosis angle per Cobb
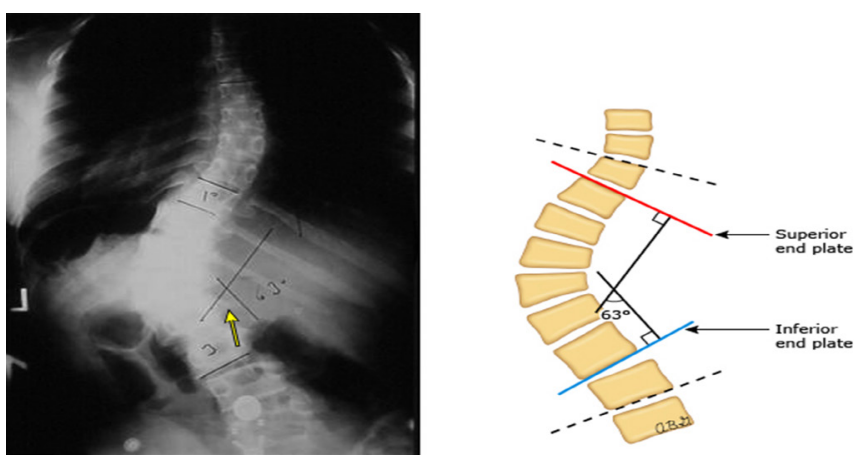

(Kane WJ. Scoliosis prevalence: a call for a statement of terms. Clin Orthop Relat Res 1977;126:43-6)

Scoliosis is a complex, three-dimensional spine deformity with a curve in frontal plane, with rotation in a horizontal plane and a change of profile in a sagittal plane. According to the definition, (up to date), idiopathic scoliosis represents a pathological entity of unknown and probably not a single cause. ${ }^{2-4}$ Based on data from year 2007, the prevalence of scoliosis among school children in Serbia was 10.2\% which, in comparison with data from year 1997 is an increase of $1.4 \%$. Progression of scoliotic curves which require treatment is significantly more frequent, even up to the eight times higher among girls. The proportion of affected girls increases with the increase of the curve degrees. ${ }^{5}$ The worst prognosis is linked with thoracic idiopathic scoliosis which develops in first five years of life. The reason is the interference with lung development and its secondary impact on restirictive respiratory disorders, hypoxemia, pulmonary hypertension, chronic pulmonary hearth, cardiac decompensation and respiratory insufficiency. Some authors state that idiopathic scoliosis over 700 leads to the irreversible pulmonary damage. As a rule, adolescent idiopathic scoliosis over 1000 causes the damage to lungs. ${ }^{6-8}$

Chronic venous diseases encompass a group of pathological conditions which are developed due to increased venous pressure leading to progressive stasis and consequent inflammatory and trophic changes of subfascial structures, subcutaneous tissue and skin. Risk factors for development of chronic venous diseases include age, family history of venous diseases, loosening of ligaments, prolonged standing, the BMI increase, smoking, sedentary life style, trauma of lower extremities, previous venous thrombosis, the presence of an arteriovenous shunt, some hereditary factors, high estrogen and pregnancy. ${ }^{9-14}$ Diagnosis of varicose veins is established following the assessment done by the angiologist. The assessment includes the clinical examination of superficial veins and ultrasound assessment of deep veins of lower extremities. The findings can be as it follows:

1. Normal condition of venous system - no clinical signs and no ultrasound signs of changes.
2. Moderate diseases of venous system - clinically visible varicose veins without trophic changes with the ultrasound verification of obstruction in superficial veins or in perforate veins (stage $\mathrm{C}_{2}-3$ according to CEAP Classification).

3. Severe venous disease - clinically visible trophic changes with the ultrasound verification of obstruction in deep veins system (stage C4-6 according to CEAP Classification). ${ }^{14}$

Theories which link the uterine descent with idiopathic scoliosis are theories discussing the role of connective tissue in building the key structures responsible for stability of perineum but also the stability of the entire locomotor apparatus. ${ }^{14-16}$ Diagnosis of uterine prolapse is based on gynecological examination which can verify three degrees of uterine descent:

1. First degree (descensus uteri) - the cervix is below the interspinal line but above the introitus of vagina.

2. Second degree (prolapsus uteri) - is the higher degree of descent whereby the cervix and part of vagina descent to the level of introitus, and sometimes the cervix is outside of introitus.

3. Third degree (prolapsus uteri totalis) - the highest degree of the static disorder whereby the entire uterus and vagina are outside of introitus. ${ }^{16-18}$

In the context of this study, the starting theory is that bone instabilities are associated with changes in collagen strength and its metabolism. Further on, the assumption is that factor of connective tissue (its quality) is one of the important factors in multifactorial etiopathogenesis. Some studies have showed that, in certain hereditary pathological conditions, the loss of matrix protein in skin has an impact on blood vessels and that varicose veins are more frequently present in those disorders. One of such disorders is idiopathic scoliosis. ${ }^{18-20}$ The change in collagen synthesis is described in findings of varicose veins as such. Smoot muscle cells extracted from varicose veins were synthetizing more type I collagen, less type III collagen and similar quantities of collagen $\mathrm{V}$. This disbalance is a possible reason for mechanic traits of the tissue which, under such conditions, has a lower quality. ${ }^{21}$ Also, more findings indicate the relationship between connective tissue disorders, also some other hereditary disorders and onset of the pelvic organ descent. ${ }^{21-23}$ Hence, there is an assumption that these two conditions are parts of the same entity as the idiopathic scoliosis.

\section{Aims of the Study}

The main aim of this study is to determine the presence of varicose veins and/or uterine prolapse in women 
previously treated for idiopathic scoliosis and in women who have never been treated for idiopathic scoliosis, then to compare these two groups.

\section{Patients and Methods}

The study was designed as a cross-sectional study which followed the presence of varicose veins and/or uterine prolapse in group of women who were previously assessed and treated by Team for scoliosis at the Institute for physical medicine and rehabilitation „Dr Miroslav Zotovićin Banja Luka. All participants have undergone the study procedures during the period $08 / 01 / 2015$ - 12/30/2015. Inclusion criteria were: female sex, reproductive age, medical records about the type of treatment, signed informed consent for participation in the study; exclusion criteria were: scoliosis which developed as part of some other, diagnosed condition or trauma and pregnancy. At the time of the study, a control group with women of approapriate age was established. They were recruited among female patients who happened to be in-patients in rehabilitation programs at the Institute for physical medicine and rehabilitation „Dr Miroslav Zotović“ in Banja Luka, for other pathological processes on locomotor apparatus and who had never been treated for idiopathic scoliosis. All participants in the control group were exposed to the same examinations and the same questions.

Based on medical records from the Team for scoliosis, all participants were grouped according to the type of treatment, which at the same time determined the severity / degree of scoliosis:

1. Group 1 (Participants treated with physiotherapy only),

2. Group 2 (Participants treated with combination of physiotherapy and application of orthosis / corset)

3. Group 3 (Participants treated with surgery)
Assessment of the venous system was done by a specialist of physical medicine and rehabilitation - subspecialist angiologist. Clinical examination of superficial veins of lower extremities was complemented with the ultrasound examination done with LOGIQ P6 PRO apparatus. Based on obtained data, the condition of venous system was classified as normal condition, moderate venous disease and severe venous disease, as previously described.

The gynecological examination was performed in all participants who were previously treated for idiopathic scoliosis and in all participants in the control group. The examination included clinical gynecological examination and grading of the uterus descent, which was then classified in three different degrees, as previously described.

Data collected in this study were recorded in MS Excel 2007 database, while the statistical program SPSS 17 was used for all statistical analyses. Data were processed using the standard statistical methods, both from domain of descriptive statistics and domain of statistical deduction (nonparametric $\mathrm{X}^{2}$ test). The value of $\mathrm{P}<0.05$ was taken as a cut off for statistically significant values. For assessment of the sample size, the study used formula and nomogram tables according to Cohen. The conclusion was that valid statistical assessment requires minimum of 86 participants. This study was approved by the respective Ethical Committee.

\section{Results}

Results are presented through two modalities: descriptive data and data obtained with tests of statistical deduction. Tables and graphs were used to display results.

\section{Descriptive presentation of the obtained data}

We have shown descriptive statostocalfeatures for age at which the treatment started, current age, body mass and body height, for both groups, the experimental and the control one (Table 1).

Table 1. Descriptive display of the observed parameters

\begin{tabular}{ccccccc}
\hline Idiopathic scoliosis & The average value & Mode & Median & SD & Min. & Max. \\
\hline Age when treatment started $^{\star}$ & 11.7 & 12 & 12 & 2.9 & 6 & 17 \\
Current age* $^{\star}$ & 30.9 & 20 & 34 & 7.9 & 20 & 43 \\
Body mass $^{\star \star}$ & 63.6 & 60 & 62 & 9.6 & 45 & 86 \\
Body height $^{\star \star \star}$ & 168.6 & 164 & 167 & 6.5 & 157 & 186 \\
\hline Control group & The average value & Mode & Median & SD & Min. & Max. \\
\hline Current age $^{\star}$ & 29.9 & 27 & 29 & 6.7 & 17 & 42 \\
Body mass $^{\star \star}$ & 67 & 66 & 66 & 12.7 & 43.5 & 119 \\
Body height $^{\star \star *}$ & 169 & 169 & 169 & 6.2 & 144 & 188 \\
\hline
\end{tabular}

*age; $\quad$ **body mass in kilograms;

***body height in centimeters 
Graph 1. indicates the representation of certain treatment modalities for idiopathic scoliosis in the experimental group.

Graph 1. Distribution of the type of treatment for idiopathic scoliosis in the experimental group

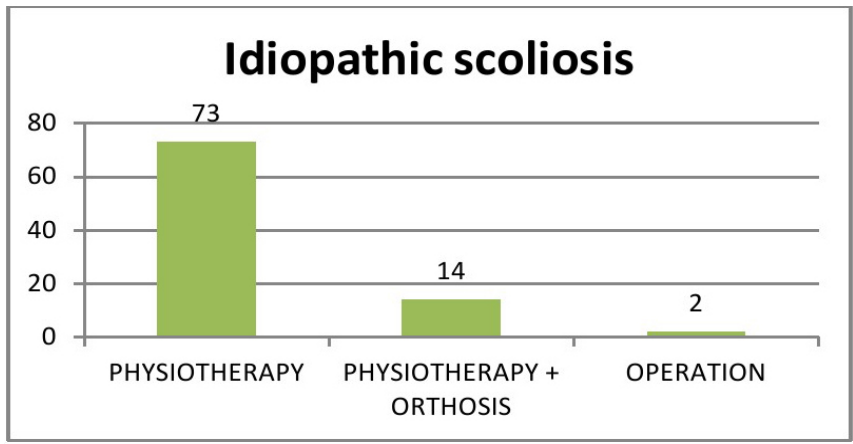

Graph 2. indicates the presence of varicose veins in experimental in comparison with the control group.

Graph 2. Presence of the varicose veins in experimental and control group

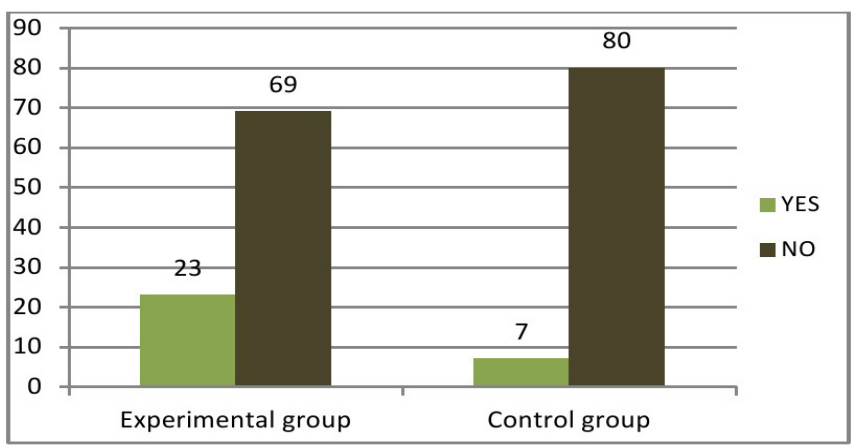

Considering the fact that there was not a single case of uterine prolapse, we did not present those data in graph.

\section{The use of tests of statistical deduction}

Table 2. Varicose veins and uterine prolapse in experimental and control group

\begin{tabular}{cccc}
\hline & $\begin{array}{c}\text { Experimental } \\
\text { group } \\
(\mathrm{n}=89)\end{array}$ & $\begin{array}{c}\text { Control } \\
\text { group } \\
(\mathrm{n}=87)\end{array}$ & $\begin{array}{c}\text { Asym. } \\
\text { Sig } \\
(2 \text { tailed })\end{array}$ \\
Varicose veins & 23 & 7 & $0.002^{*}$ \\
Uterine prolapse & 0 & 0 & $* *$ \\
\hline
\end{tabular}

${ }^{*} X 2=9.854 ; d f 1 ;(p<0.01)$

**no statistical test was done

\section{Discussion}

Experimental group (women treated for the idiopathic scoliosis) included 89 women, while the control group (women who had never been treated for idiopathic scoliosis) included 87 women. Based on data presented in Table 1, the average value for the current age in experimental group was 30.9, and in the control group 29.9; as for the body height, the average value in experimental group was $168.6 \mathrm{~cm}$, and in the control group $169 \mathrm{~cm}$; body weight - in experimental group the average value was $63.6 \mathrm{~cm}$, while in the in the control group was $67 \mathrm{~kg}$. Values of these parameters are close and we can state that, by these parameters, the control group is very similar to the experimental group.

In our context, the age at which diagnosis of idiopathic scoliosis was established and treatment started varies between 6 and 17 years (the middle value was 11.7). This corresponds with a period of the most intense growth, when visual and functional deficit becomes most pronounced but also at age when the self-inspection is most present and most critical.

Graph 1. shows the distribution according to the treatment type (stage of disorder) for the idiopathic scoliosis. Majority of participants were treated with physiotherapy only (PT) - 73 participants (82\%), with the combined treatment (PT) + corset in 14 participants (15.7\%), and following the surgical treatment in 2 participants $(2.3 \%)$. Such results are in line with scientific facts as the highest percentage of mild degree deformities can be corrected pretty quickly with an adequate treatment and only a small percentage requires more serious approach. The first recommendation is the early detection and referral for conservative treatment which prevents the progression of the curve and complications linked to the advanced scoliosis, while the use of orthosis should be combined with physical treatment whenever necessary. The latter can be seen as assistance during the intense growth, with an aim to prevent the severe deformity which in turn requires more serious correction. In the sample of this study, there were only two cases of surgical treatment. One participant had surgery at the age of 9 , the other at the age of 15 , both with satisfactory effect.

Graph 2. displays the distribution of varicose veins in experimental group and in the control group. It is visible that varicose veins were more common in the experimental (23/89; 25.8\%) then in the control group $(7 / 87 ; 8.1 \%)$.

Table 2. shows the distribution of varicose veins in population of women who were treated for the idiopathic scoliosis in comparison with the control group. Using the nonparametric $\mathrm{X}^{2}$ test we obtained value $\mathrm{X}^{2}=9.854$; for df1, Asymp.Sig ( 2 tailed) $=0.002<0.01$, which rejects the hypothesis about the variables independence and accepts the hypothesis that the difference is statistically significant ( $\mathrm{p}<0.01)$. Hence, women who were treated for idiopathic scoliosis had the statistically significant frequency of the varicose veins presence. 
In the context of this study, the starting theory is that bone instabilities are associated with changes in the collagen strength and its metabolism. Further on, it is assumed that in multifactorial etiopathogenesis, one of the important factors is connective tissue (quality). As the results of this study revealed that presence of varicose veins is more common in women who used to be treated for idiopathic scoliosis, we can state that the theory about the impact of connective tissue may have the bigger influence than it is assumed.

As there was not a single case of the uterine prolapse in our sample, we analyzed data from previous similar studies. One study from year 2000 was following the prevalence of the urinary incontinence and pelvic organs prolapse in women with Marphan's syndrome and Ehlers Danlos syndrome. All findings were indicative for the possible etiological relations between the connective tissue disorders and pelvic organs prolapse. In 2000, Mattox and associates presented the correlation study for abnormal curve of the vertebral column and prolapse of the pelvic organs. This study was the continuation of the study done by Lind et al., who followed the relationship between the thoracic spine kyphosis and uterine prolapse. Mettox and associates concluded that the abnormal change in spine curve, particularly loss of lumbar lordosis may be a significant risk factor for development of the prolapse of the organs in minor pelvis.. ${ }^{24,25}$ Based on data and findings from the literature, we believe that age structure of our participants was the key factor which explains why we did not find a single uterine prolapse in the entire sample.

\section{Conclusion}

The presence of varicose veins in women treated for idiopathic scoliosis shows a statistically significant difference when compared with the women in the control group. The study did not find a single case of the uterine prolapse in either experimental or control group and possible reason is the age of participants.

Based on the results of the study, we can conclude that beside the treatment for idiopathic scoliosis we need to look for other conditions or disorders which can worsen the condition or make the treatment more complicated.

Modern approach to treatment of idiopathic scoliosis requires specialized multidisciplinary teams for scoliosis in facilities which developed expertise. Teams should engage in prevention, early diagnostics and adequate treatment.

Idiopathic scoliosis should be seen as a disorder of multifactorial ethiopathogenesis and be treated accordingly, especially considering its potential to cause the damage to vital organic systems (circulatory system and lungs).

\section{Reference}

1. Negrini S, Grivas TB, Kotwicki T, Rigo M, Zaina F. Why do we treated adolescent idiopatic scoliosis? SOSORT 2005 Consensus paper. Scoliosis 2006;1-4.

2. Grivas TB, Burwell GR, Vasiliadis ES, Webb JK. A segmental radiological study of the spine and rib-cage in children with progressive Infantile Idiopathic Scoliosis. Scoliosis 2006;1:1-17. http://dx.doi.org/10.1186/1748-7161-1-17 PMid:17049098 PMCid:PMC1635062

3. Grivas TB, Vasiliadis ES, Rodopoulos G, Bardakos N. The role of the intervertebral disc in correction of scoliotic curves. A theoretical model of idiopathic scoliosis pathogenesis. Stud Health Technol Inform 2008;140:33-6. PMid:18809995

4. Grivas TB, Vasiliadis ES, Rodopoulos G. Aetiology of Idiopathic Scoliosis. What have we learned from school screening? Stud Health Technol Inform 2008;140:240-4. PMid:18810030

5. Institut za javno zdravlje Srbije "Dr Milan Jovanović Batut": Zdravlje stanovnika Srbije, analitička studija 1997-2007, Beograd, 2008, available from: http://www.batut.org.rs/ linkovi.html.

6. Weinstein SL, Dolan LA, Spratt KF, Peterson KK, Spoonamare MJ, Ponseti IV. Health and function of patients with untreated idiopatic scoliosis: A 50 year natural history study. JAMA 2003;289:559-67.

http://dx.doi.org/10.1001/jama.289.5.559

PMid:12578488

7. Weinstein SL, Ponseti IV. Curve progression in idiopatic scoliosis. J Bone Joint Surg Am 1983;65.447-55.

8. Weinstein Sl, Zavala DC, Ponseti IV. Idiopatic scoliosis. Long term follow up and prognosis in untreated patients. J Bone Joint Surg Am 1981;63:702-12. PMid:6453874

9. Brand FN, Dannenberg AL, Abbott RD, Kannel WB. The epidemiology of varicose veins: the Framingham Study. Am J Prev Med 1988;4:96-101.

PMid:3395496

10. Callam MJ. Epidemiology of varicose veins. Br J Surg 1994;81:167-173.

http://dx.doi.org/10.1002/bjs.1800810204

PMid:8156326

11. Chiesa R, Marone EM, Limoni C, Volonte M, Petrini O. Chronic venous disorders: correlation between visible signs, symptoms, and presence of functional disease. J Vasc Surg 2007;46:322-30.

http://dx.doi.org/10.1016/j.jvs.2007.04.030

PMid:17600668

12. Scott TE, LaMorte WW, Gorin DR, Menzoian JO. Risk factors for chronic venous insufficiency: a dual case-control study. J Vasc Surg 1995;22:622-8. http://dx.doi.org/10.1016/So741-5214(95)70050-1

13. Fowkes FG, Lee AJ, Evans CJ, Allan PL, Bradbury AW,Ruckley CV. Lifestyle risk factors for lower limb venous reflux in the general population: Edinburgh Vein Study. Int 
J Epidemiol 2001;30:846-52.

http://dx.doi.org/10.1093/ije/30.4.846

PMid:11511615

14. SadickNS. Predisposing factors of varicose and telangiectatic leg veins. J Dermatol Surg Oncol 1992;18:883-6.

http://dx.doi.org/10.1111/j.1524-4725.1992.tbo2921.x PMid:1430543

15. Iannuzzi A, Panico S, Ciardullo AV, Bellati C, Cioffi V, Iannuzzo G, et al. Varicose veins of the lower limbs and venous capacitance in postmenopausal women: relationship with obesity. J Vasc Surg 2002;36:965-8. http://dx.doi. org/10.1067/mva.2002.128315 PMid:12422106

16. Evans CJ, Fowkes FG, Hajivassiliou CA, Harper DR, Ruckley CV. Epidemiology of varicose veins. A review. Int Angiol 1994;13:263-270 http://dx.doi.org/10.1006/hmat.1994.1034

17. Browse NL. The etiology of venous ulceration. World J Surg 1986;10:938-43.

http://dx.doi.org/10.1007/BFo1658644

PMid:3798942

18. Browse NL, Burnand KG. The cause of venous ulceration. Lancet 1982;2:243-5.

http://dx.doi.org/10.1016/So140-6736(82)90325-7

19. Darvall KA, Sam RC, Adam DJ, Silverman SH, Fegan CD, Bradbury AW. Higher prevalence of thrombophilia in patients with varicose veins and venous ulcers than controls. J Vasc Surg 2009;49:1235-41.

http://dx.doi.org/10.1016/j.jvs.2008.12.017

PMid:19307088
20. Allison MA, Cushman M, Callas PW, Denenberg JO, Jensky NE, Criqui MH. Adipokines are associated with lower extremity venous disease: the San Diego population study. J Thromb Haemost 2010;8:1912-8.

http://dx.doi.org/10.1111/j.1538-7836.2010.03941.x

PMid:20546124 PMCid:PMC4078899

21. Serra R, Buffone G, de Franciscis A. A genetic study of chronic venous insufficiency. Ann Vasc Surg 2012;26:63642.

http://dx.doi.org/10.1016/j.avsg.2011.11.036

PMid:22664280

22. Anwar MA, Georgiadis KA, Shalhoub J, Lim CS, Gohel MS, Davies AH. A review of familial, genetic, and congenital aspects of primary varicose vein disease. Circ Cardiovasc Genet 2012;5:460-6. http://dx.doi.org/10.1161/ CIRCGENETICS.112.963439 PMid:22896013

23. Vlajinac HD, Radak DJ, Marinkovic JM, Maksimovic MZ. Risk factors for chronic venous disease. Phlebology 2012;27:416-22.

http://dx.doi.org/10.1258/phleb.2011.011091

PMid:22345329

24. Vlajinac HD, Marinkovic JM, Maksimovic MZ, Matic PA, Radak DJ. Body mass index and primary chronic venous disease-a cross-sectional study. Eur J Vasc Endovasc Surg 2013;45:293-8.

http://dx.doi.org/10.1016/j.ejvs.2012.12.011

PMid:23337196

25. Lee AJ, Evans CJ, Allan PL, Ruckley CV, Fowkes FG. Lifestyle factors and the risk of varicose veins: Edinburgh Vein Study. J Clin Epidemiol 2003;56:171-9. 


\section{Proširene vene i prolaps materice kod pacijentkinja liječenih od idiopatske skolioze}

\section{SAŽETAK}

Uvod: U dostupnim literaturnim izvorima postoje izolovani podaci o vezi poremećene sinteze kolagena i loše posture sa pojavom proširenih vena i prolapsa materice, ali ciljanih studija nema.

Cilj rada: Utvrditi učestalost proširenih vena i/ili prolapsa materice kod žena liječenih od idiopatske skolioze u odnosu na kontrolnu grupu - žene koje nikada nisu liječene zbog idiopatske sklolioze.

Ispitanici i metode: Studija je kreirana kao studija presjeka. Učestalost proširenih vena i prolapsa materice kod žena liječenih od idiopatske skolioze je posmatrana u odnosu na kontrolnu grupu. Rezultati su obrađeni deskriptivno i upotrebom testova statističkog zaključivanja, a vrijednosti gdje je $\mathrm{p}<0.05$ uzete su kao statistički značajne.

Diskusija: Učestalost proširenih vena je statistički značajno veća u grupi žena koje su liječene zbog idiopatske skolioze u odnosu na kontrolnu grupu, dok nije zabilježen niti jedan slučaj prolapsa materice.

Zaključak: Savremeni pristup liječenju idiopatske skolioze podrazumijeva postojanje multidisciplinarnih timova za skoliozu u ustanovama koje se bave ovom problematikom. Njihov zadatak je rad na prevenciji, ranoj dijagnostici, adekvatnom terapijskom pristupu zasnovanom na medicinskim dokazima, ali i kontinuirana istraživačka aktivnost koja za cilj ima poboljšanje kvaliteta života.

Ključne riječi: idiopathic scoliosis, varicose veins, uterine prolapse, collagen 